\title{
Scholars and Literati at the Royal Dublin Society (1757-1800)
}

\author{
Valentine Debois $\quad$ David de la Croix
}

IRES/LIDAM, UCLouvain

This note is a summary description of the set of scholars and literati who were members or associates of the Royal Dublin Society from its inception in 1731 to the eve of the Industrial Revolution (1800).

\section{The ACADEMY}

The Royal Dublin Society like the Royal Society of London, the Oxford Philosophical Society, Gresham College, the Dublin Philosophical Society, or even Trinity College were created thanks to the will of a certain number of scientists who used to meet to discuss various topics of interest to them (McClellan 1985). The Royal Dublin Society was created after the first English Revolution during which Ireland took advantage of the confused situation to try to regain its independence, without success. After the Revolution, the country was trying to regain its former calm and tranquility, but the state of agriculture was extremely poor. Fortunately, there was a very cultured society in Dublin, and there were many thoughtful men all over Ireland concerned with improving the condition of their country and raising the status of the rural population. The founding of the Dublin Society therefore fell to a small group of patriotic reformers. Although the Society soon began to meet in a committee room of Parliament, its first meeting was held in the Halls of the Philosophical Society at Trinity College on June 25, 1731. The names of those who thus stood round the cradle of the infant Society must ever be held in honor in Ireland, and, though all were men of note, the names of at least eight stand out prominently as having, from the start and for years after, labored assiduously and unselfishly to promote the ends it had in view. Here are the names of these 8 men: Michael Ward, Thomas Molyneux, John Whitecombe, Arthur Dobbs, William Stephens, Francis Le Hunte, and Thomas Prior. Primarily, they set for themselves the task of educating those concerned in the first principles of successful farming, and of endeavoring to promote industries which might afford employment. They aimed at making Ireland not only self-supplying, but also a great exporting nation. Initially, the aim of the Royal Dublin Society, also known by the abbreviation RDS was to "improve agriculture, industry and other useful arts," but on July 8, 1731, two weeks after its initial foundation, the mention "And sciences" is added. The society still exists today (https://www.rds.ie).

\section{SOURCES}

The data collected in this document comes from a single source: a book entitled "A History of the Royal Dublin Society," written by Henry F. Berry (1915), a barrister-at-law. It gathers members who were active in the Society from its creation until after the end of the 18th century. Two main lists are established: one with the members in 1733 and the other with those active from 1750 onward. This source alone induces a problem of disambiguation: the people entered in the database have their names included in the lists, but there is still some uncertainty about their actual identity. 


\section{SOME STATISTICS}

Table 1 shows some descriptive statistics. These statistics have been divided into 2 periods:

- 1686-1733: There are 228 scholars, and the year of birth is known for about half of them (54.4\%). The mean age at nomination is 49.3 years, while the mean age at death is slightly higher than 68 years. For $37.7 \%$ of these scholars, the birthplace is known. The median distance between the academy and the locations of birth is $146 \mathrm{~km}$. Almost half of the scholars counted have a Wikipedia page (41.7\%), and $36.8 \%$ of them have left a footprint in Worldcat, the catalogues of the libraries of the world. It means that $36.8 \%$ of the scholars published some works, books and/or articles.

- 1734-1800: There are only 140 scholars, and the year of birth is known for about three quarters of them (74.3\%). The mean age at nomination as well as the mean age at death are lower than in the previous period: 35.6 years for the average age at nomination and 64.6 years for the average age at death. Life expectancy at age 30 is also lower. For $40.7 \%$ of these scholars, the birthplace is known and the median distance between the academy and the locations of birth is $176 \mathrm{~km}$. A little more than half of the scholars counted have a Wikipedia page written in some language (55\%), and $43.6 \%$ of them have left a footprint in Worldcat.

\begin{tabular}{|c|c|c|c|c|c|c|}
\hline \multicolumn{2}{|c|}{ Period } & nb. & $\%$ birth year & mean age & mean age & life exp. \\
\hline Start & End & obs & known & at nomin. & at death & at 30 \\
\hline 1686 & 1733 & 228 & 54.4 & 49.3 & 68.8 & 65.9 \\
\hline 1734 & 1800 & 140 & 74.3 & 35.6 & 64.6 & 62 \\
\hline & & $\begin{array}{c}\% \\
\text { nepotism }\end{array}$ & $\begin{array}{c}\% \text { birth place } \\
\text { known }\end{array}$ & $\begin{array}{l}\text { median distance } \\
\text { birth-institution }\end{array}$ & $\begin{array}{c}\% \text { with } \\
\text { Wikipedia }\end{array}$ & $\begin{array}{c}\% \text { with } \\
\text { Worldcat }\end{array}$ \\
\hline 1686 & 1733 & 0.4 & 37.7 & 146 & 41.7 & 36.8 \\
\hline 1734 & 1800 & 2.9 & 40.7 & 176 & 55 & 43.6 \\
\hline
\end{tabular}

Table 1: Summary statistics by period

\section{FIELDS}

Figure 1 shows the proportion of the different fields taught at the academy. We notice that a third of the fields taught are unknown. This is due to the fact that only one source was used to characterize the academy, and many of the individuals mentioned remain quite unknown. The remainder of the pie chart shows that about half of the scholars were related to either law or religion, or were honorary members. Only a sixteenth of the pie chart concerns the fields of humanities, medicine, sciences, and applied sciences.

\section{Place of Birth}

Figure 2 is a plot of the places of birth of the members of the Royal Dublin Society. Most scholars were born in England and Ireland. Note, however, that the locations of birth are evenly distributed in Ireland, while in England most scholars were born in the south. We observe that only 4 scholars were born outside this zone: 2 in central Europe and 2 outside Europe. 


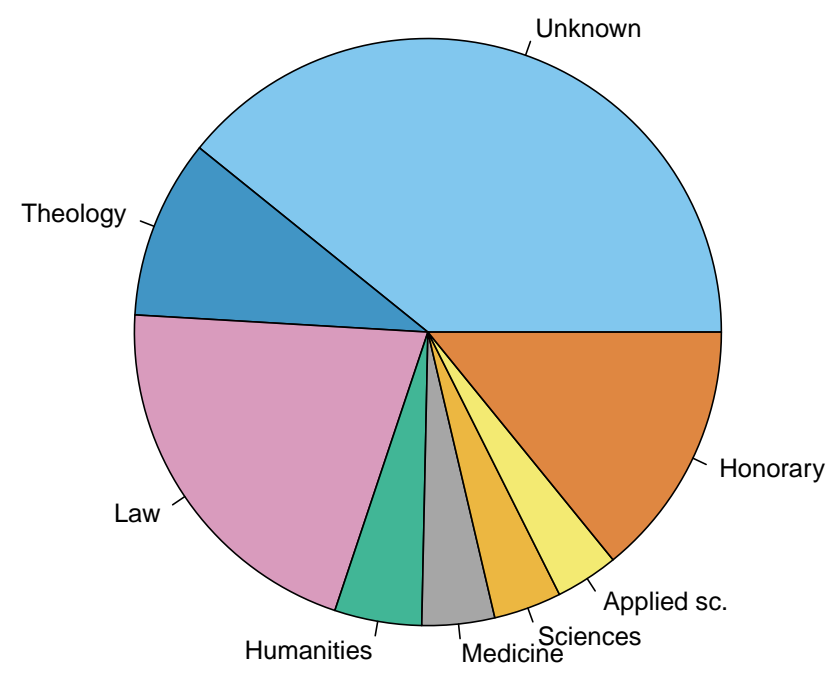

Figure 1: Broad fields at the Royal Dublin Society

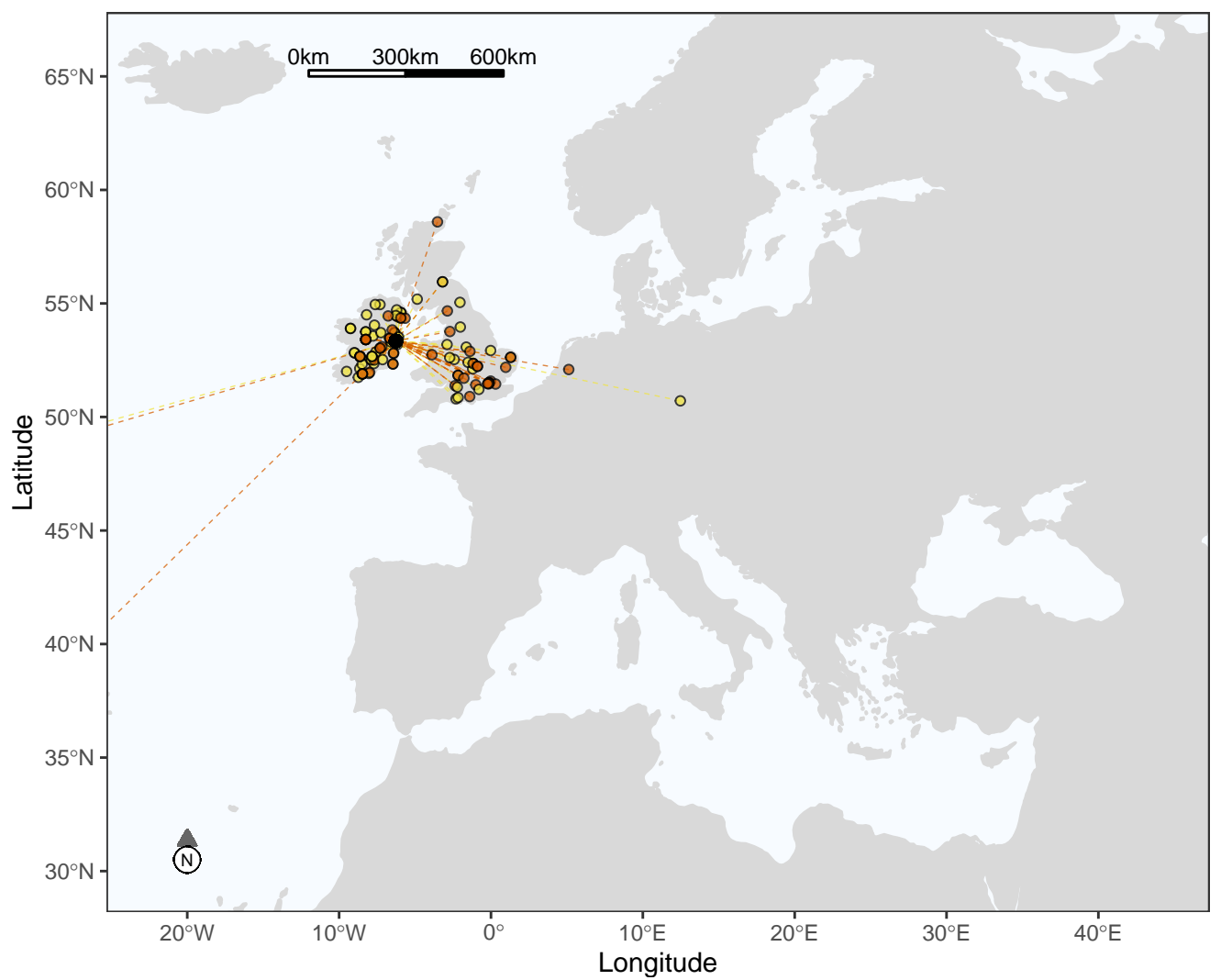

Figure 2: Places of birth of the scholars at the Royal Dublin Society 


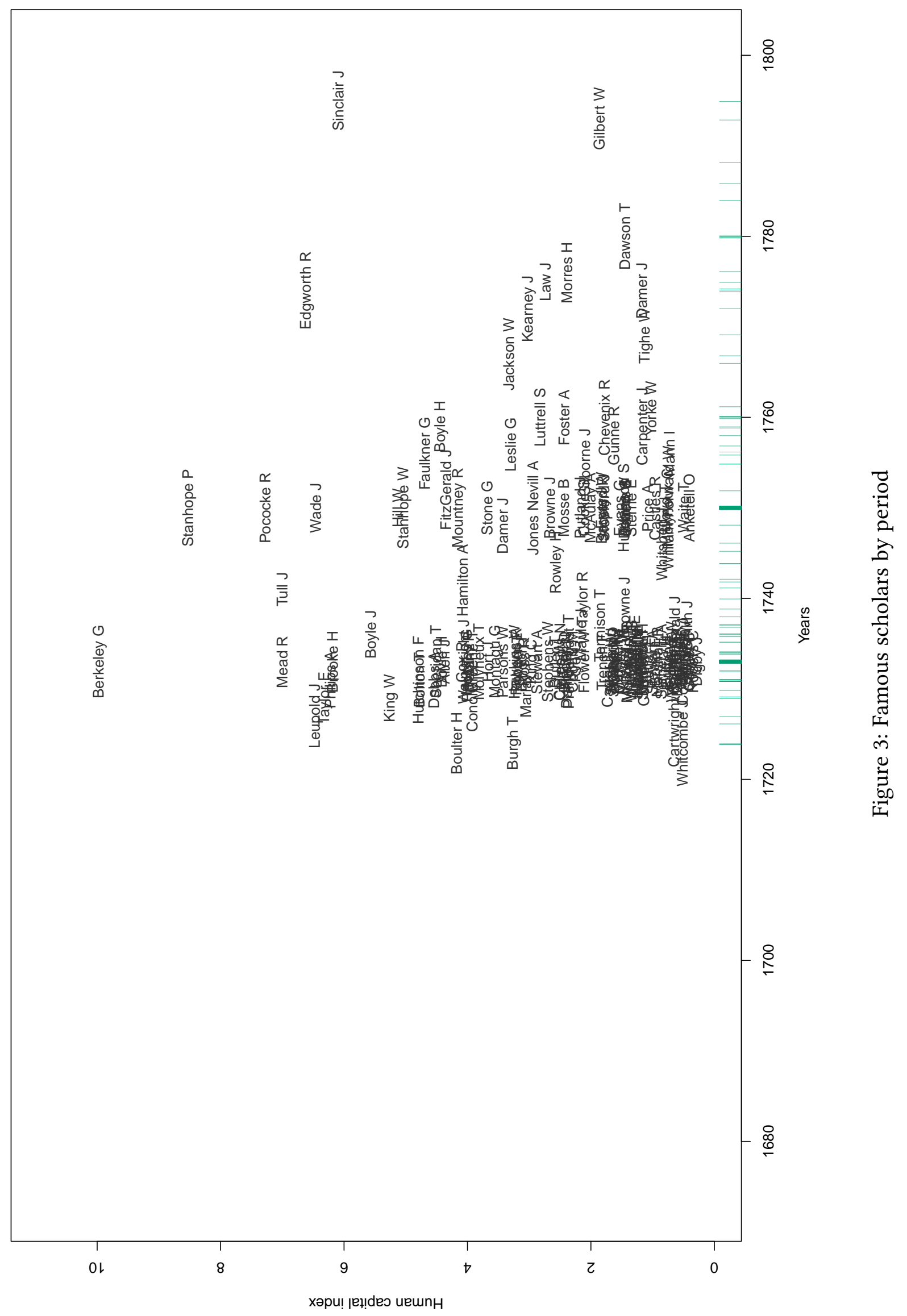




\section{HUMAN CAPITAL OF SCHOLARS AND LITERATI}

We attribute a heuristic human capital index to each person encoded in the database. This index is calculated on the basis of information found on Worldcat and Wikipedia using principal component analysis. The details are given in any issue of RETE in volumes 1-5. Figure 3 shows the names of all scholars with a positive human capital index. The vertical green lines (rug plot) show the distribution of all these scholars over time (counting from the start of their working life). The scholars with the highest index were appointed before 1760. Most other scholars have an index below 5 .

\section{TOP 5 SCHOLARS}

We now provide a brief overview of the five scholars with the highest human capital index.

George Berkeley (Thomastown 1685 - Oxford 1753) was a philosopher born in Ireland. When young, he taught Greek at Trinity College, Dublin, before becoming a member of the Royal Dublin Society in 1733. Also known as "Bishop Berkeley" or even the "Bishop of Cloyne," he was one of the precursors of the theory of immaterialism. As its name suggests, this theory denies the existence of matter and therefore affirms that there are only spiritual or immaterial beings in the world. He wrote several works supporting this theory including "An Essay Towards a New Theory of Vision" and "A Treatise Concerning the Principles of Human Knowledge." Berkeley also argued against Isaac Newton's ideas of absolute space, time, and motion.

Philip Stanhope (London 1694 - London 1773) was the 4th Earl of Chesterfield, so he was known as Lord Chesterfield or even Philip Dormer Stanhope. He was a politician and more particularly a member of the "Whig" party. This party was in favor of a strong parliament by opposing royal absolutism. Stanhope was also a writer. He became a member of the Royal Dublin Society in 1745, while he was the General Governor of Ireland. He wrote many letters of advice on life to his son (who was named after him) during a long trip to the mainland. He was also a member of the Académie des inscriptions in Paris.

Richard Pococke (Southampton 1704 - Tullamore 1765) was the Bishop of Ossory and Meath. He was also Lord Chesterfield's chaplain. His family connections enabled him to advance rapidly in the church. He traveled extensively in Europe and the Middle East. He is best known for his travel writings and diaries. His travels allowed him to collect fossils, stones, minerals, etc. His collection, as well as a coin and medals, was bequeathed to the British Museum. He was a member of both the Royal Society of London and the Royal Dublin Society.

Richard Mead (London 1673 - Bloomsbury 1754) was one of the few physicians of the Royal Dublin Society. More precisely, his field of activity was epidemiology. He notably contributed to the understanding of communicable diseases. He studied in the Netherlands (Utrecht and Leiden) and graduated in philosophy and physics from Padua in 1695. He returned to London immediately after graduation to practice. In 1703, he was elected physician to St. Thomas' Hospital. Subsequently, while he was in the service of the king, Mead became involved in the creation of a new charity: the Foundling Hospital, both as a founding governor but also as an advisor on all medical matters.

Jethro Tull (Berkshire 1674 - Hungerford 1741) was one of the Society's few agronomists. His book entitled "New Horse Hoeing Husbandry" was the first book printed at the Royal Dublin Society. This book presents a technique for cleaning soil and removing weeds using a horsedrawn machine. Tull is the author of other inventions to facilitate agriculture. In particular, he worked on creating a machine that could sow seeds faster than when done by hand.

Note that all these scholars were either born or died in England. Figure 2 may explain this pattern. Indeed, this figure shows that a large share of the scholars who were members of the Royal Dublin 
Society were born in England. This might also reflect strong links between England and its close colony after the Glorious Revolution.

\section{FAMILIES OF SCHOLARS}

Within the Royal Dublin Society, we counted 4 father - son pairs: Damer, Dawson, Monck, and Stratford.

\section{INTERSECTIONS WITH NEARBY UNIVERSITIES}

Figure 4 shows that some members of the Royal Dublin Society were also fellows or professors at the University of Dublin, Trinity College (from Burtchaell and Sadleir (1935)). However, 15/366 is a small number, and the interactions between the University and the Society must have been limited.

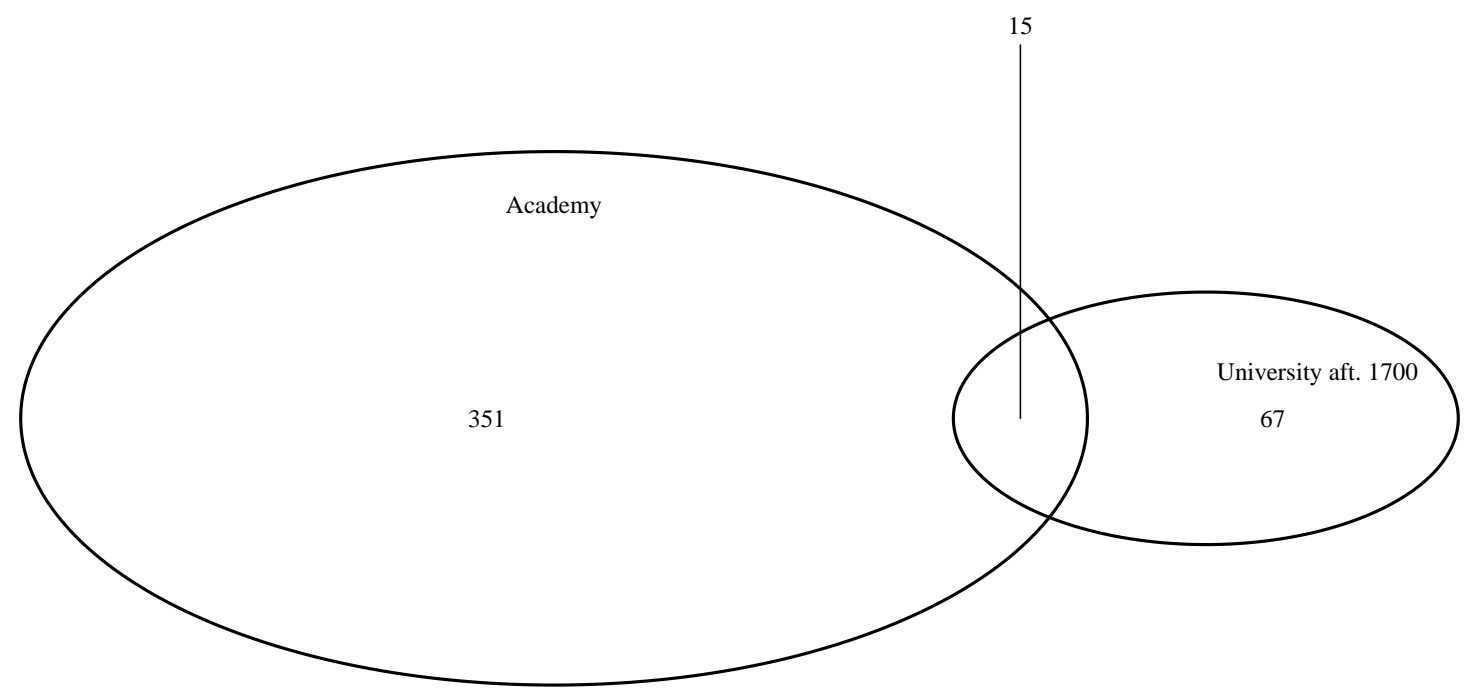

Figure 4: Intersections of the lists of scholars between the University of Dublin and the Royal Dublin Society

\section{AnecDotes}

It may be that Tull's book about a horse-drawn machine inspired the Royal Dublin Society a few years later. Indeed, in 1868, the first horse show was organized by the Society. This competition was one of the first jumping competitions ever organized. Over time, it has grown into a top international show jumping competition, a national competition, and a major entertainment event in Ireland. In 1982, the Royal Dublin Society hosted the world show jumping championships and incorporated them into the "Dublin Horse Show" that year. Nowadays, the Simmoncourt pavilion serves, for a week, as a stable for jumping horses during the "Dublin Horse Show." The aim of the Society in 1731, which was to improve agriculture, industry, other useful arts and sciences, is therefore still relevant today.

\section{ACKNOWLEDGMENTS}

This project has received funding from the European Research Council (ERC) under the European Union's Horizon 2020 research and innovation programme under grant agreement No 883033 "Did elite human capital trigger the rise of the West? Insights from a new database of European scholars."

First version December 19, 2021. 


\section{REFERENCES}

Berry, Henry Fitz-Patrick. 1915. A history of the Royal Dublin Society. Longmans, Green / Company.

Burtchaell, George Dames, and Thomas Ulick Sadleir. 1935. Alumni dublinenses: a register of the students, graduates, professors and provosts of Trinity College in the University of Dublin (15931860). A. Thom \& Company, Limited.

McClellan, James E. 1985. Science Reorganized: Scientific Societies in the Eighteenth Century. New York: Columbia University Press. https://doi.org/10.2307/2739060. 